\title{
Prolonged Exposure of Human Pancreatic Islets to High Glucose Concentrations In Vitro Impairs the $\beta$-Cell Function
}

Décio L. Eizirik, * Gregory S. Korbutt, ${ }^{\star}$ and Claes Hellerström*

${ }^{*}$ Department of Medical Cell Biology, Uppsala University, S-751 23 Uppsala, Sweden; ${ }^{\ddagger}$ Department of Metabolism and Endocrinology, Vrije Universiteit Brussel, and B-Cell Transplant, 1090 Brussels, Belgium

\begin{abstract}
The aim of the present study was to clarify whether prolonged in vitro exposure of human pancreatic islets to high glucose concentrations impairs the function of these cells. For this purpose, islets isolated from adult cadaveric organ donors were cultured for seven days in RPMI 1640 medium supplemented with $10 \%$ fetal calf serum and containing either 5.6 , 11, or 28 $\mathrm{mM}$ glucose. There was no glucose-induced decrease in islet DNA content or signs of morphological damage. However, islets cultured at 11 or $28 \mathrm{mM}$ glucose showed a 45 or $60 \%$ decrease in insulin content, as compared to islets cultured at 5.6 $\mathrm{mM}$ glucose. Moreover, when such islets were submitted to a 60-min stimulation with a low $(1.7 \mathrm{mM})$ followed by a high (16.7 $\mathbf{m M}$ ) concentration of glucose, the islets cultured at $\mathbf{5 . 6}$ $\mathrm{mM}$ glucose showed a higher insulin response to glucose than those of the two other groups. Islets cultured at the two higher glucose concentrations showed increased rates of insulin release in the presence of low glucose, and a failure to enhance further the release in response to an elevated glucose level. Islets cultured at $28 \mathrm{mM}$ glucose showed an absolute decrease in insulin release after stimulation with $16.7 \mathrm{mM}$ glucose, as compared to islets cultured at $5.6 \mathrm{mM}$ glucose. The rates of glucose oxidation, proinsulin biosynthesis, and total protein biosynthesis were similar in islets cultured at 5.6 or $11 \mathrm{mM}$ glucose, but they were decreased in islets cultured at $28 \mathrm{mM}$ glucose. These combined results suggest that lasting exposure to high glucose concentrations impairs the function of human pancreatic islets. (J. Clin. Invest. 1992. 90:1263-1268.) Key words: pancreatic islets $\bullet$ glucose $\bullet$ insulin release $\bullet$ glucose oxidation • proinsulin biosynthesis
\end{abstract}

\section{Introduction}

There are several studies showing that intensive insulin therapy in the early stages of insulin-dependent diabetes mellitus $(\text { IDDM })^{1}$ can improve and preserve $\beta$-cell function (1-3). These observations suggest that the increased glucose levels prevailing in early IDDM are somehow deleterious for the $\beta$-cells.

Address correspondence to Dr. Décio L. Eizirik, Department of Medical Cell Biology, Biomedicum, P. O. Box 571, S-751 23 Uppsala, Sweden.

Received for publication 11 February 1992 and in revised form 28 April 1992.

1. Abbreviation used in this paper: IDDM, insulin-dependent diabetes mellitus.

J. Clin. Invest.

(C) The American Society for Clinical Investigation, Inc. 0021-9738/92/10/1263/06 \$2.00

Volume 90, October 1992, 1263-1268
Indeed, the possibility of glucose-induced pancreatic $\beta$-cell damage has been much debated in the literature (for recent reviews see 4,5 ). According to this idea, the defective insulin response to glucose observed in the early phases of IDDM, and in non-insulin-dependent diabetes mellitus, would reflect a chronic hyperglycaemic stimulation of a reduced $\beta$-cell mass $(4,5)$. Experimental support for this concept relies mainly on animal models, like the neonatal injection of streptozotocin, partial pancreatectomy, and in vivo infusion of glucose (4-6). However, it has been difficult to demonstrate these glucose effects under tissue culture conditions. Thus, while some groups reported that culture of rodent islets in the presence of high glucose concentrations impairs $\beta$-cell function ( $7-11$ ), we and others were unable to observe any deleterious effects of glucose in vitro (12-18). Possible explanations for these discrepancies are the use of different culture conditions, and genetic differences between the experimental models. Indeed, recent findings suggest that hyperglycemia may be injurious to pancreatic islets obtained from C57BL/Ks mice, but not to islets obtained from C57BL/6 mice (19).

These observations raise the question to what extent human islets are sensitive to the potential deleterious effects of high glucose concentrations. Due to major problems in obtaining well-characterized human islets under culture conditions, it has been difficult to address this issue properly.

In the current study human islets were isolated from cadaveric donors. Following a detailed characterization of the islet cell populations, they were cultured at different glucose concentrations $(5.6,11$, or $28 \mathrm{mM})$ for one week. After this period the islet glucose-stimulated insulin release, the number of islets retrieved after culture, the islet DNA and insulin content, and the rates of glucose oxidation and proinsulin biosynthesis were evaluated. The combined data suggest that lasting exposure to high glucose impairs the function of human islets.

\section{Methods}

Islet isolation. 14 human pancreata were excised from adult cadaveric organ donors at European hospitals affiliated with the $\beta$-Cell Transplant-European Concerted Action for the Treatment of Diabetes, Brussels, Belgium. The mean age of the donors $( \pm \mathrm{SEM})$ was $38 \pm 3 \mathrm{yr}$ (range of 18-54 yr). Each gland was flushed and cooled $\left(4^{\circ} \mathrm{C}\right)$ in situ with University of Wisconsin or Eurocollins solutions. The glands were then removed and transported to the Central Unit of the $\beta$-Cell Transplant (Medical Campus, Vrije Universiteit Brussel, Brussels, Belgium). At the Central Unit the glands were processed by ductal distension with collagenase, gentle dissociation, and Ficoll gradient purification of islets, as previously described (20). Aliquots of the purified suspension were examined by electron microscopy, which indicated $<10 \%$ dead cells in all preparations, and the presence of $6.6 \pm 2.3 \%$ exocrine cells ( mean $\pm \mathrm{SEM} ; n=14$ ). The prevalence of insulin-positive cells, as evaluated by light microscopical examination of immunocytochemically stained islets, varied between 23 and $61 \%$ in the different preparations 
$(35 \pm 4 \%, n=14)$, and the islet insulin content was $1.3 \pm 0.2 \mathrm{ng}$ insulin/ ng DNA.

Islet culture. After isolation, the islets were cultured in Ham F10 medium (Flow Laboratories, Irvine, Strathclyde, UK) containing 6.1 $\mathrm{mM}$ glucose, and supplemented with $0.5 \%$ bovine serum albumin, 0.08 $\mathrm{mg} / \mathrm{ml}$ penicillin, and $0.1 \mathrm{mg} / \mathrm{ml}$ streptomycin. The culture period in Brussels varied between 22 and $168 \mathrm{~h}$ (mean \pm SEM, 75.7 $\pm 12.9 \mathrm{~h}, n$ $=14$ ), and the islets were subsequently sent by air to Uppsala, Sweden, in the same medium as described above, supplemented with $2 \%$ newborn calf serum and $10 \mathrm{mM}$ Hepes (transport time: 4-8 h). Functional and morphological examinations (see below) of the islets immediately upon arrival in Uppsala showed no signs of islet damage induced by the transport procedure (data not shown). The first three preparations received in Uppsala were used to elaborate optimal conditions for tissue culture over a 7-d period. The variables examined were: type of culture medium (RPMI 1640 versus Ham F10, both from Flow Laboratories); type of serum (FCS versus pooled human serum); and serum concentration ( $1 \%$ versus $10 \%$ ). The data (not shown) suggested that the best functional outcome (as evaluated by islet retrieval, islet insulin and DNA contents, insulin release in response to glucose, and rates of glucose oxidation) was obtained with islets maintained free-floating in RPMI 1640 medium containing $5.6 \mathrm{mM}$ glucose and supplemented with $10 \%$ FCS (Flow Laboratories), benzylpenicillin $(100 \mathrm{U} / \mathrm{ml})$, and streptomycin $(0.1 \mathrm{mg} / \mathrm{ml})$ (culture conditions as in reference 21$)$. Islets maintained for seven days in Ham F10 medium supplemented with $10 \%$ FCS presented a similar insulin and DNA content as observed in islets maintained in RPMI 1640. However, the absolute rates of islet insulin release at $16.7 \mathrm{mM}$ glucose after culture in Ham F10 (insulin release studied as described below) was only half of that in islets cultured in RPMI 1640 (data not shown). After these initial experiments, all subsequent batches of human islets received in Uppsala were cultured in groups of 100-150 islets/dish in RPMI 1640 medium containing $10 \%$ FCS, as described above. The medium was supplemented either with $5.6,11$, or $28 \mathrm{mM}$ glucose, and was changed every two days. At every medium change aliquots of the medium were frozen for subsequent insulin determination by radioimmunoassay (22). In some experiments, groups of islets were transferred for a further 2-d culture at $5.6 \mathrm{mM}$ glucose after the initial 7-d culture at the different glucose concentrations. Light microscopical examinations were performed of paraffin sections of Bouin-fixed islets immunocytochemically stained for insulin and counterstained with hematoxylin.

Islet insulin release, DNA and insulin contents, glucose oxidation, proinsulin, and total protein biosynthesis. For the insulin release experiments, the islets were divided into triplicate groups of seven islets each and placed in sealed glass vials containing $0.25 \mathrm{ml}$ bicarbonate buffer (23) supplemented with $10 \mathrm{mM}$ Hepes and $2 \mathrm{mg} / \mathrm{ml}$ albumin (KRBH buffer $)$. During the first hour of incubation at $37^{\circ} \mathrm{C}\left(\mathrm{O}_{2}: \mathrm{CO}_{2} ; 95: 5\right)$ the $\mathrm{KRBH}$ medium contained $1.7 \mathrm{mM}$ glucose. The medium was then gently removed and replaced by $0.25 \mathrm{ml} \mathrm{KRBH}$ supplemented with $16.7 \mathrm{mM}$ glucose, followed by incubation for a second hour. The insulin concentration in the incubation medium was determined by radioimmunoassay (22). After the insulin release experiments, the islets were pooled and disrupted by sonication in $0.2 \mathrm{ml}$ bidistilled water. A $50-\mu \mathrm{l}$ aliquot of the aqueous homogenate was mixed with $125 \mu \mathrm{l}$ acid ethanol and the insulin extracted overnight at $4^{\circ} \mathrm{C}$. DNA was measured fluorophotometrically in another fraction of the water homogenate (24). To measure islet glucose oxidation rates, triplicate groups of 10 islets were transferred to glass vials containing $\mathrm{D}-\left[\mathrm{U}-{ }^{14} \mathrm{C}\right]$ glucose (Amersham International, Amersham, UK) and nonradioactive glucose to a final concentration of 1.7 or $16.7 \mathrm{mM}$ glucose (sp act $0.5 \mathrm{mCi} / \mathrm{mM}$ ) in medium $\mathrm{KRBH}$, without albumin. The determination of the glucose oxidation rates were performed as previously described (25).

For the study of proinsulin and total protein biosynthesis, groups of 20 islets were placed in multiwell plates (well capacity $0.4 \mathrm{ml}$; Linbro Chemical Co., Hamden, CT), containing $100 \mu \mathrm{l} \mathrm{KRBH}$ supplemented with either 1.7 or $16.7 \mathrm{mM}$ glucose and $\mathrm{L}-\left[4,5-{ }^{3} \mathrm{H}\right]$ leucine (Amer- sham; final concentration of $50 \mu \mathrm{Ci} / \mathrm{ml}$ ) and incubated in $95 \%$ air $+5 \% \mathrm{CO}_{2}$ for $2 \mathrm{~h}$ at $37^{\circ} \mathrm{C}$. The islets were subsequently washed with Hanks' solution containing nonradioactive leucine $(10 \mathrm{mM})$ and sonicated in redistilled water. Proinsulin and insulin were separated from other proteins in the islet homogenates by means of an immunobinding technique (26). Total protein biosynthesis was estimated by measurements of the radioactivity after trichloroacetic acid precipitation of a fraction of the homogenate. Another fraction of the homogenate was used to determine DNA contents, as described above.

Statistical analysis. Data are presented as means \pm SEM, and groups of data were compared using the paired Student's $t$ test. In all experimental series each islet preparation (i.e., islets obtained from one donor) was considered as one individual observation. When experiments were performed in duplicate or triplicate, a mean was calculated and considered as one separate observation. The coefficients of correlation were obtained by simple linear regression, and the statistical significance of the correlations were evaluated by analysis of variance.

\section{Results}

The loss of islets after the 7-d culture period was $\sim 10 \%$ in all groups ( Table I). Exposure of the islets to high glucose concentrations did not modify retrieval of islets or the islet DNA content. Moreover, light microscopical examination revealed wellpreserved islets, with no evidence of cell necrosis in any of the studied groups (a detailed account of the islet morphology will be published elsewhere). However, islets cultured at 11 or 28 $\mathrm{mM}$ glucose had a much lower insulin content than islets cultured at $5.6 \mathrm{mM}$ glucose (Table I).

During the whole period of observation, culture of human islets at both 11 or $28 \mathrm{mM}$ glucose induced an increased insulin accumulation in the medium, as compared to islets cultured in the presence of $5.6 \mathrm{mM}$ glucose (Table II). In each of the three experimental groups there was a progressive decrease in insulin accumulation into the medium over the six days of culture. This was especially marked in the islets cultured at $28 \mathrm{mM}$ glucose. Thus, in these islets the insulin release into the medium decreased by $75 \%$ over the culture period, while in islets cultured at $5.6 \mathrm{mM}$ glucose there was a $40 \%$ decrease over the same period of time. After seven days in culture at $5.6 \mathrm{mM}$ glucose, the human islets showed a 6.1-fold increase in insulin release in response to an acute glucose stimulation (Table III). Islets cultured at $11 \mathrm{mM}$ glucose had a higher insulin release at $1.7 \mathrm{mM}$ glucose than islets cultured at $5.6 \mathrm{mM}$ glucose. How-

Table I. Islet Retrieval, DNA, and Insulin Contents of Human Islets after Seven Days in Culture at Different Glucose Concentrations

\begin{tabular}{cccc}
\hline $\begin{array}{c}\text { Medium } \\
\text { glucose }\end{array}$ & $\begin{array}{c}\text { Islet } \\
\text { retrieval }\end{array}$ & $\begin{array}{c}\text { DNA } \\
\text { content }\end{array}$ & $\begin{array}{c}\text { Insulin } \\
\text { content }\end{array}$ \\
\hline$m M$ & $\%$ & ng/10 islets & $n g / 10$ islets \\
5.6 & $88 \pm 3$ & $300 \pm 28$ & $229 \pm 52$ \\
11 & $88 \pm 3$ & $304 \pm 32$ & $125 \pm 29^{*}$ \\
28 & $90 \pm 2$ & $277 \pm 37$ & $88 \pm 29^{*}$
\end{tabular}

Human islets were maintained in tissue culture at different glucose concentrations for seven days. The islet retrieval was expressed as the percentage of islets remaining in culture on day 7 as compared to day 0 . The results are means \pm SEM of $9-11$ observations. ${ }^{*} P<0.01$ when compared to islets cultured at $5.6 \mathrm{mM}$ glucose. 
Table II. Insulin Accumulation in a Medium Containing Human Islets over a Six-Day Period in Culture at Different Glucose Concentrations

\begin{tabular}{cccc}
\hline \multirow{2}{*}{$\begin{array}{c}\text { Medium } \\
\text { glucose }\end{array}$} & Days 1-2 & Days 3-4 & Days 5-6 \\
\cline { 2 - 4 } & & $n g / 100$ islets $\times 48 h$ \\
$m M$ & $920 \pm 146$ & $676 \pm 135$ & $576 \pm 60$ \\
5.6 & $2,378 \pm 568^{*}$ & $1,430 \pm 249^{\ddagger}$ & $1,152 \pm 223^{\ddagger}$ \\
11 & $4,660 \pm 982^{\ddagger}$ & $1,791 \pm 336^{\ddagger}$ & $1,186 \pm 112^{\S}$ \\
28 & & & \\
\hline
\end{tabular}

Human islets were maintained in culture as described in Table I. Medium was collected for insulin determinations at 48-h intervals. The results are means \pm SEM of 9-10 observations, each performed in duplicate. ${ }^{*} P<0.02 ;{ }^{\ddagger} P<0.01 ;{ }^{\S} P<0.001$ when compared to islets cultured at $5.6 \mathrm{mM}$ glucose.

ever, these islets failed to increase further their insulin release in response to a glucose stimulus (increase ratio $=1$ ). Islets cultured at $28 \mathrm{mM}$ glucose also presented a high insulin release at $1.7 \mathrm{mM}$ glucose. As observed in islets cultured at $11 \mathrm{mM}$ glucose, islets cultured at $28 \mathrm{mM}$ glucose failed to increase the insulin release in response to $16.7 \mathrm{mM}$ glucose (increase ratio $<1$ ). However, during short-term incubations at $16.7 \mathrm{mM}$ glucose islets cultured at $11 \mathrm{mM}$ glucose secreted similar amounts of insulin in response to glucose as islets cultured at $5.6 \mathrm{mM}$ glucose, whereas in these experiments islets maintained at 28 $\mathrm{mM}$ glucose showed an absolute decrease in insulin secretion.

Culture in the presence of high glucose concentrations also impaired the insulin release in response to $16.7 \mathrm{mM}$ glucose $+5 \mathrm{mM}$ theophylline. Thus, islets previously cultured at 5.6 $\mathrm{mM}$ glucose released $41.9 \pm 14.2 \mathrm{ng}$ insulin $/ 10$ islets $\times 60 \mathrm{~min}$ (experimental conditions as described in Table III; the basal insulin release at $1.7 \mathrm{mM}$ glucose was $3.2 \pm 0.3 \mathrm{ng}$ insulin / 10 islets $\times 60 \mathrm{~min}$ and the increase ratio in response to glucose plus theophylline, 18.0 $\pm 5.4, n=5$ ), while islets cultured at 11

Table III. Glucose-stimulated Insulin Release of Human Islets Maintained for Seven Days in Culture at Different Glucose Concentrations

\begin{tabular}{cccc}
\hline & \multicolumn{3}{c}{ Insulin release } \\
\cline { 2 - 4 } $\begin{array}{c}\text { Medium } \\
\text { glucose }\end{array}$ & $\begin{array}{c}\text { 1st h } \\
(1.7 \mathrm{mM} \text { glucose })\end{array}$ & $\begin{array}{c}2 \mathrm{nd} \mathrm{h} \\
(16.7 \mathrm{mM})\end{array}$ & $\begin{array}{r}\text { Increase ratio } \\
\text { (vs. } 1.7 \mathrm{mM})\end{array}$ \\
\hline$m M$ & & $n g / 10$ islets $\times 60 \mathrm{~min}$ \\
& & $17.5 \pm 3.6$ & $6.1 \pm 1.4$ \\
5.6 & $3.1 \pm 0.3$ & $17.0 \pm 4.3$ & $1.0 \pm 0.2^{\ddagger}$ \\
11 & $20.7 \pm 6.3^{*}$ & $8.1 \pm 1.8^{\S}$ & $0.9 \pm 0.3^{\ddagger}$ \\
28 & $11.8 \pm 3.3^{\S}$ & & \\
\hline
\end{tabular}

Human islets were cultured as described in Table I. Islet insulin release experiments were performed by incubating groups of seven islets in $\mathrm{KRBH}$ containing $1.7 \mathrm{mM}$ glucose. After $60 \mathrm{~min}$ at $37^{\circ} \mathrm{C}$ the medium was removed and the islets incubated for another $60 \mathrm{~min}$ in $\mathrm{KRBH}$ containing $16.7 \mathrm{mM}$ glucose. The increase ratio was determined in each experiment by dividing the insulin release in the second hour by that in the first hour of incubation. The results are means \pm SEM of nine observations, each performed in triplicate. ${ }^{\S} P<0.05 ;^{*} P<0.02 ;{ }^{\ddagger} P<0.01$ when compared to islets cultured at $5.6 \mathrm{mM}$ glucose.
Table IV. Glucose Oxidation of Human Islets after Seven Days in Culture at Different Glucose Concentrations

\begin{tabular}{|c|c|c|}
\hline \multirow{2}{*}{$\begin{array}{l}\text { Medium } \\
\text { glucose }\end{array}$} & \multicolumn{2}{|c|}{ Glucose oxidation } \\
\hline & $1.7 \mathrm{mM}$ glucose & $16.7 \mathrm{mM}$ glucose \\
\hline$m M$ & \multicolumn{2}{|c|}{$\mathrm{pmol} / 10$ islets $\times 90 \mathrm{~min}$} \\
\hline 5.6 & $115 \pm 21$ & $380 \pm 50$ \\
\hline 11 & $104 \pm 23$ & $353 \pm 60$ \\
\hline 28 & $79 \pm 15^{*}$ & $279 \pm 57^{\ddagger}$ \\
\hline
\end{tabular}

Human islets were maintained in culture as described in Table I. Rates of glucose oxidation were measured in groups of 10 islets for 90 min in KRBH buffer (without albumin) supplemented with D-[U${ }^{14} \mathrm{C}$ ]glucose and 1.7 or $16.7 \mathrm{mM}$ nonradioactive glucose (sp act 0.5 $\mathrm{mCi} / \mathrm{mmol})$. The results are means $\pm \mathrm{SEM}$ of seven observations, each performed in triplicate. ${ }^{*} P<0.01^{\ddagger} P<0.05$; whem compared to islets cultured at $5.6 \mathrm{mM}$ glucose.

$\mathrm{mM}$ glucose released $31.0 \pm 10.9 \mathrm{ng}$ insulin $/ 10$ islets $\times 60 \mathrm{~min}$ (the basal insulin release at $1.7 \mathrm{mM}$ glucose was $12.9 \pm 3.5 \mathrm{ng} /$ 10 islets $\times 60 \mathrm{~min}$ and the increase ratio, $2.4 \pm 0.4 ; n=5 ; P$ $<0.05$ when compared to the increase ratio of islets cultured at $5.6 \mathrm{mM}$ glucose) and islets cultured at $28 \mathrm{mM}$ glucose released $10.3 \pm 2.6 \mathrm{ng}$ insulin / 10 islets $\times 60 \mathrm{~min}$ (the basal insulin release at $1.7 \mathrm{mM}$ glucose was $5.4 \pm 0.9 \mathrm{ng} / 10$ islets $\times 60 \mathrm{~min}$ and the increase ratio, $1.9 \pm 0.2 ; n=5 ; P<0.05$ when compared to the increase ratio of islets cultured at $5.6 \mathrm{mM}$ glucose). The pooled DNA content of islets studied in this experimental series was $193 \pm 29 \mathrm{ng} / 10$ islets $(n=15)$, and there were no differences between the DNA contents of islets cultured at 5.6,11, or $28 \mathrm{mM}$ glucose (data not shown).

There was a positive correlation $(P<0.02)$ between the islet insulin content and the islet insulin release in response to $16.7 \mathrm{mM}$ glucose in all groups studied. The coefficients of correlation between insulin release and insulin content were, respectively, $0.70,0.61$, and 0.93 for the islets cultured at either $5.6,11$, or $28 \mathrm{mM}$ glucose.

The glucose oxidation rates were similar in islets cultured at 5.6 and $11 \mathrm{mM}$ glucose (Table IV). However, islets cultured at $28 \mathrm{mM}$ glucose showed decreased rates of glucose oxidation in the presence of both 1.7 or $16.7 \mathrm{mM}$ glucose, as compared to islets maintained at $5.6 \mathrm{mM}$ glucose.

The contribution of proinsulin to the total pool of labeled proteins in the human islets was in the range of $7-10 \%$, independently of the glucose concentration in the medium (Table V). There were no differences in the proinsulin or total protein biosynthesis rates between islets cultured at 5.6 or $11 \mathrm{mM}$ glucose. However, islets cultured at $28 \mathrm{mM}$ glucose presented a decreased proinsulin and total protein biosynthesis when exposed to $16.7 \mathrm{mM}$ glucose. Moreover, while islets cultured at $5.6 \mathrm{mM}$ glucose doubled their rate of proinsulin biosynthesis in response to $16.7 \mathrm{mM}$ glucose, islets cultured at $28 \mathrm{mM}$ glucose failed to increase the insulin biosynthesis in response to the hexose.

To assess if the functional impairment induced by high glucose was reversible, islets from the three culture groups were exposed to an additional 2-d culture at $5.6 \mathrm{mM}$ glucose (Table VI). After this period, there was still a $20-40 \%$ decrease in insulin content in islets precultured at 11 or $28 \mathrm{mM}$ glucose 
Table V. Proinsulin and Total Protein Biosynthesis of Human Islets after Seven Days in Culture at Different Glucose Concentrations

\begin{tabular}{|c|c|c|c|c|}
\hline \multirow{2}{*}{$\begin{array}{l}\text { Medium } \\
\text { glucose }\end{array}$} & \multicolumn{2}{|c|}{ Proinsulin biosynthesis } & \multicolumn{2}{|c|}{ Total protein biosynthesis } \\
\hline & $1.7 \mathrm{mM}$ & $16.7 \mathrm{mM}$ & $1.7 \mathrm{mM}$ & $16.7 \mathrm{mM}$ \\
\hline$m M$ & \multicolumn{2}{|c|}{$10^{2}$ dpm $/ 10$ islets $\times 2 h$} & \multicolumn{2}{|c|}{$10^{2}$ dpm $/ 10$ islets $\times 2 \mathrm{~h}$} \\
\hline 5.6 & $35 \pm 3$ & $89 \pm 20$ & $571 \pm 71$ & $954 \pm 168$ \\
\hline 11 & $47 \pm 8$ & $86 \pm 22$ & $607 \pm 98$ & $936 \pm 137$ \\
\hline 28 & $43 \pm 9$ & $40 \pm 5^{*}$ & $598 \pm 98$ & $615 \pm 97^{\ddagger}$ \\
\hline
\end{tabular}

Human islets were maintained in culture as described in Table I. Rates of proinsulin biosynthesis were measured by an immune absorption technique, and total protein biosynthesis was estimated by measuring the incorporation of $\mathrm{L}-\left[4,5-{ }^{3} \mathrm{H}\right]$ leucine $(50 \mu \mathrm{Ci} / \mathrm{ml})$ into trichloroacetic-precipitable proteins. The islets in groups of 20 were incubated for $2 \mathrm{~h}$ in KRBH medium supplemented with 1.7 or 16.7 $\mathrm{mM}$ glucose, as indicated. The results are means \pm SEM of eight observations. ${ }^{*} P<0.05 ;^{\ddagger} P<0.01$ when compared to islets cultured at $5.6 \mathrm{mM}$ glucose.

and then transferred to culture at $5.6 \mathrm{mM}$ glucose, but this reduction was less marked than that observed immediately after seven days exposure to high glucose (Table I). The 2-d culture at $5.6 \mathrm{mM}$ glucose also improved the insulin increase ratio in the islets previously cultured at 11 or $28 \mathrm{mM}$ glucose (Table VI; compare with values in Table III). The higher values for the increase ratio in the 11-5.6 and 28-5.6 groups were mainly due to a decrease in the insulin release at $1.7 \mathrm{mM}$ glucose, which was now around 3.5-5.0 ng insulin / 10 islets $\times 60$ min in both groups, similar to the values observed in islets cultured at $5.6 \mathrm{mM}$ glucose during the whole period of observation.

\section{Discussion}

The data obtained in the present study suggest that exposure to high glucose concentrations affects the function of human islets in a dose-dependent way. Thus, culture at $11 \mathrm{mM}$ glucose mainly impaired the ability of the $\beta$-cells to increase their insulin output when sequentially challenged with a low $(1.7 \mathrm{mM})$ and a high ( $16.7 \mathrm{mM})$ glucose concentration. On the other hand, culture at a higher glucose concentration $(28 \mathrm{mM})$ not only decreased insulin release at $16.7 \mathrm{mM}$ glucose, but also affected glucose metabolism and protein biosynthesis, suggesting a more widespread impairment in islet function. The data on proinsulin biosynthesis, however, should be interpreted with caution, due to the possibility that culture at different glucose concentrations may modify the rate of conversion of proinsulin to insulin, and thus affect the immunoprecipitation of labelled proteins.

It is noteworthy that culture conditions identical to those used in the present study did not induce deleterious effects after exposure to 16.7 or $28 \mathrm{mM}$ glucose of islets isolated from mice $(15,16,18)$ and rats (27). Moreover, culture at high glucose in most cases tended to increase, rather than decrease, islet function $(15,16,18,27)$. Only in one study, in which rat islets were exposed to extremely high glucose concentrations ( $56 \mathrm{mM}$ ) for one week (28), was it possible to observe an effect similar to that of $11 \mathrm{mM}$ glucose in human islets, i.e., a failure of the islets
Table VI. Insulin Content and Glucose-stimulated Insulin Release of Human Islets Maintained for Seven Days in Culture at Different Glucose Concentrations and then Cultured for Two Additional Days at $5.6 \mathrm{mM}$ Glucose

\begin{tabular}{ccccc}
\hline & & \multicolumn{3}{c}{ Insulin release } \\
\cline { 3 - 5 } $\begin{array}{c}\text { Medium } \\
\text { glucose }\end{array}$ & $\begin{array}{c}\text { Insulin } \\
\text { content }\end{array}$ & $\begin{array}{c}1 \mathrm{st} \mathrm{h} \\
(1.7 \mathrm{mM})\end{array}$ & $\begin{array}{c}2 \mathrm{nd} \mathrm{h} \\
(16.7 \mathrm{mM})\end{array}$ & $\begin{array}{c}\text { Increase ratio } \\
(\text { vs. } 1.7 \mathrm{mM})\end{array}$ \\
\hline$m M$ & $n g / 10$ islets & & $n g / 10$ islets $\times 60 \mathrm{~min}$ \\
& & & & \\
$5.6-5.6$ & $294 \pm 74$ & $2.7 \pm 0.3$ & $18.5 \pm 6.3$ & $6.5 \pm 1.8$ \\
$11-5.6$ & $225 \pm 58^{*}$ & $3.7 \pm 0.5$ & $15.0 \pm 4.4$ & $3.9 \pm 0.7$ \\
$28-5.6$ & $164 \pm 40$ & $4.8 \pm 1.5$ & $10.3 \pm 2.0$ & $2.7 \pm 0.5$ \\
& & & & \\
\hline
\end{tabular}

Human islets were precultured at different glucose concentrations (5.6, 11 , or $28 \mathrm{mM}$ glucose) for seven days and then exposed to an additional 2-d culture at $5.6 \mathrm{mM}$ glucose. At the end of this 9-d period, the sequential islet insulin release in response to $1.7 \mathrm{mM}$ and $16.7 \mathrm{mM}$ glucose was measured as described in Table III. The results are means \pm SEM of seven to eight observations, each performed in triplicate. ${ }^{*} P<0.05$ when compared to islets cultured during the whole period at $5.6 \mathrm{mM}$ glucose (group 5.6-5.6).

to further increase the insulin release in response to glucose. These combined data suggest that the sensitivity of $\beta$-cells to glucose may be species specific (19), and that human islets are more affected by the deleterious effects of hyperglycemia than islets isolated from rodents. This is in line with the in vivo observations that prolonged exposure to hyperglycemia may cause permanent diabetes in cats (29) and dogs (30), but not in rats (31).

Another possibility is that the function of human islets may be more affected by the in vitro conditions than that of islets obtained from rodent species, thus inducing a special sensitivity to further functional loads, like high glucose. The islet isolation procedure is probably more traumatic to the human $\beta$ cells than to the $\beta$-cells isolated from rats and mice. This may be due to the higher content of fibrous tissue in the human pancreas, and the longer periods of warm and cold ischemia inherent in the procurement of human organs. These difficulties in human islet isolation may also explain the presence of just $30-60 \%$ insulin-positive cells in most preparations. However, the observations that human islets maintained in culture at $5.6 \mathrm{mM}$ glucose show a well-preserved insulin release and proinsulin biosynthesis in response to glucose (present data), and that manifest glucose "toxicity" cannot be shown in rodent islets even when culture at high glucose is superimposed on previous toxic- or autoimmune-mediated damage $(16,18)$, reinforce the possibility of relevant differences among species in the sensitivity to the hexose. Finally, in a recent study in which human islets were isolated by another procedure, and cultured in a different medium (CMRL 1066), it was also observed that culture of the islets at high glucose concentrations (16.7 $\mathrm{mM}$ glucose) for $48 \mathrm{~h}$ impaired glucose-induced insulin release (32).

The mechanisms behind the deleterious effects of glucose on human islets remain to be clarified. The observation that culture in the presence of $28 \mathrm{mM}$ glucose induced a marked decrease in islet insulin content, and a decrease in islet glucose metabolism, suggests that depletion of secretory insulin pools and a defective hexose metabolism contribute to a deficient 
glucose-induced insulin release. Indeed, the close correlation between the islet insulin content and insulin release observed in the different experimental groups reinforce the possibility that a glucose-induced decrease in insulin content may contribute to the impaired insulin release. The decrease in islet insulin content probably reflects a discrepancy between insulin release and proinsulin biosynthesis, leading to islet insulin depletion.

It is conceivable that other mechanisms are also relevant for the observed glucose-induced impairment in $\beta$-cell function. Thus, it has been previously suggested that exposure of rodent islets to hyperglycemia may decrease insulin release by impairing phosphoinositide hydrolysis (33), by inducing islet glycogen accumulation (34), or by directly exhausting membrane components related to the final steps of glucose-induced insulin release $(35,36)$. These possible mechanisms now need to be studied in human islets.

A main objective for the development of techniques for human islet isolation and culture is the possibility of islet transplantation as a cure for IDDM. Indeed, in recent years successful islet transplantations have been achieved in diabetic patients $(37,38)$. In light of the current data, it can be envisaged that a tight control of the glycemic levels with aggressive insulin therapy would be beneficial for the function of the graft after transplantation.

It has been previously observed that intensive insulin therapy and tight control of serum glucose improves $\beta$-cell function in early IDDM (1-3). Two main explanations for this observation have been put forward: first, that high glucose by itself may contribute to $\beta$-cell dysfunction $(4,5)$, and second, that increased functional activity would increase expression of membrane antigens by the $\beta$-cells, rendering them more vulnerable to the autoimmune aggression $(39,40)$. The present observations, suggesting that glucose directly impairs $\beta$-cell function, and recent data showing that exposure of human islets in vitro to high glucose increase the expression of the $64-\mathrm{kD} / \mathrm{GAD}$ antigen (Björk, E., O. Kämpe, F. A. Karlsson, D. Pipeleers, A. Andersson, C. Hellerström, and D. L. Eizirik, submitted for publication), suggest that both mechanisms may be operative in the early stages of IDDM.

\section{Acknowledgments}

We thank Dr. Arne Andersson for helpful discussions. The excellent technical assistance of I.-B. Hallgren, E. Törnelius, M. Enkvist, and A. Nordin is acknowledged.

This study made use of human islets prepared by the central unit of $\beta$ Cell Transplant Brussels, with the financial support of a concerted action in Medical and Health Research of the European Community. The research was also supported by grants from the Swedish Medical Research Council ( $12 \mathrm{X}-9237$, connected to the $\beta$-Cell Transplant, European Concerted Action for the Treatment of Diabetes; 12X-109; 12X-9886), the Swedish Diabetes Association, the Swedish Society of Medicine, the Hoechst Diabetes Foundation, the Novo-Nordisk Insulin Fund, the Family Ernfors Fund, the Juvenile Diabetes Foundation International, and the Belgian Fonds voor Geneeskundig Wetenschappelijk Onderzoek (3.0059.86).

\section{References}

1. Mirouze, J., J. L. Selam, T. C. Pham, and A. Orsetti. 1978. Sustained insulin-induced remission of juvenile diabetes by means of an external artificial pancreas. Diabetologia. 14:223-227.
2. Madsbad, S., T. Krarup, O. K. Faber, C. Binder, and L. Regeur. 1982. The transient effect of strict glycaemic control on B-cell function in newly diagnosed Type 1 (insulin-dependent) diabetic patients. Diabetologia. 22:16-20.

3. Shah, S., J. I. Malone, and N. E. Simpson. 1989. A randomized trial of intensive insulin therapy in newly diagnosed insulin-dependent diabetes mellitus. N. Engl. J. Med. 320:550-554.

4. Weir, G. C., J. L. Lehay, and S. Bonner-Weir. 1986. Experimental reduction of B-cell mass: implications for the pathogenesis of diabetes. Diabetes Metab. Rev. 2:125-161.

5. Rosseti, L., A. Giaccari, and R. A. DeFronzo. 1990. Glucose toxicity. Diabetes Care. 13:610-630.

6. Portha, B., O. Blondel, P. Serradas, R. C. McEvoy, M.-H. Giroix, M. Kergoat, and D. Bailbe. 1989. The rat models of non-insulin dependent diabetes induced by neonatal streptozotocin. Diabete \& Metab. 15:61-75.

7. Hoening, M., L. C. MacGregor, and F. M. Matschinsky. 1986. In vitro exhaustion of pancreatic $\beta$-cells. Am. J. Physiol. 250:E502-E511.

8. Bolaff, J. L., A. Heldt, L. D. Lewis, and G. M. Grodsky. 1986. The third phase of in vitro insulin secretion. Evidence for glucose insensitivity. Diabetes. 35:370-373.

9. Bolaffi, J. L., L. Bruno, A. Heldt, and G. M. Grodsky. 1988. Characteristics of desensitization of insulin secretion in fully in vitro systems. Endocrinology. 122:1801-1809.

10. Purrelo, F., M. Vetri, C. Gatta, D. Gullo, and R. Vigneri. 1989. Effects of high glucose on insulin secretion by isolated rat islets and purified $\beta$-cells and possible role of glycosylation. Diabetes. 38:1417-1422.

11. Kaiser, N., A. P. Corcos, I. Sarel, and E. Cerasi. 1991. Monolayer culture of adult rat pancreatic islets on extracellular matrix: modulation of B-cell function by chronic exposure to high glucose. Endocrinology. 129:2067-2076.

12. Andersson, A., J. Westman, and C. Hellerström. 1974. Effects of glucose on the ultra-structure and insulin biosynthesis of isolated mouse pancreatic islets maintained in tissue culture. Diabetologia. 10:743-753.

13. Bone, A. J., I. Swenne, and C. Hellerström. 1981. Effects of high glucose concentrations on the insulin biosynthesis of rat pancreatic islets maintained for extended periods in tissue culture. Diabete \& Metab. 7:259-263.

14. Malaisse-Lagae, F., A. Sener, and W. J. Malaisse. 1986. Can desensitization of the $\beta$-cell to glucose be simulated in cultured pancreatic islets? Acta Diabetol. Lat. 24:17-25.

15. Eizirik, D. L., E. Strandell, and S. Sandler. 1988. Culture of mouse pancreatic islets in different glucose concentrations modifies B cell sensitivity to streptozotocin. Diabetologia. 31:168-174.

16. Eizirik, D. L., and S. Sandler. 1989. Sustained exposure of toxically damaged mouse pancreatic islets to high glucose does not increase $\beta$-cell dysfunction. J. Endocrinol. 123:47-51.

17. Giroix, M.-H., P. Serradas, and B. Portha. 1989. The desensitization of normal B-cells to glucose in vitro is transient and not related to high glucose levels. Endocrinology. 125:1999-2007.

18. Eizirik, D. L., E. Strandell, and S. Sandler. 1991. Prolonged exposure of pancreatic islets isolated from "pre-diabetic" non-obese diabetic mice to a high glucose concentration does not impair beta-cell function. Diabetologia. 34:6-11.

19. Korsgren, O., L. Jansson, S. Sandler, and A. Andersson. 1990. Hyperglycemia-induced $B$ cell toxicity. The fate of pancreatic islets transplanted into diabetic mice is dependent on their genetic background. J. Clin. Invest. 86:2161-2168.

20. Warnock, G. L., D. K. Ellis, M. Cattral, D. Untch, N. M. Kneteman, and R. V. Rajotte. 1989. Viable purified islets of Langerhans from collagenase-perfused human pancreas. Diabetes. 38(Suppl. 1):136-139.

21. Andersson, A. 1978. Isolated mouse pancreatic islets in culture: effects of serum and different culture media on the insulin production of the islets. Diabetologia. 14:397-404

22. Heding, L. G. 1972. Determination of total serum insulin (IRI) in insulintreated diabetic patients. Diabetologia. 8:260-266.

23. Krebs, H. A., and K. Henseleit. 1932. Untersuchugen über die Harnstoffbildung im Tierkörper. Hoppe-Seyler's Z. Physiol. Chem. 210:33-66.

24. Hinegardner, R. T. 1971. An improved fluorimetric assay for DNA. Anal. Biochem. 39:197-201.

25. Andersson, A., and S. Sandler. 1983. Viability tests of cryopreserved endocrine pancreatic cells. Cryobiology. 20:161-168.

26. Halban, P. A., C. B. Wolheim, B. Blondel, and A. E. Renold. 1980. Longterm exposure of isolated pancreatic islets to mannoheptulose: evidence for insulin degradation in the $\beta$-cell. Biochem. Pharmacol. 29:2625-2633.

27. Welsh, N., and C. Hellerström. 1990. In vitro restoration of insulin production in islets from adult rats treated neonatally with streptozotocin. Endocrinology. 126:1842-1848.

28. Svensson, C., and C. Hellerström. 1991. Long-term effects of a high glucose concentration in vitro on the oxidative metabolism and insulin production of isolated rat pancreatic islets. Metab. Clin. Exp. 40:513-518.

29. Dohan, F. C., and F. E. W. Lukens. 1947. Lesions of the pancreatic islets produced in cats by administration of glucose. Science (Wash. DC). 105:183. 
30. Imamura, T., M. Koffler, J. H. Helderman, D. Prince, R. Thirlby, L. Inman, and R. H. Unger. 1988. Severe diabetes induced in subtotally depancreatize dogs by sustained hyperglycemia. Diabetes. 37:600-609.

31. Komiya, I., D. Baetens, M. Kuwajima, and R. H. Unger. 1990. Compensatory capabilities of islets of $\mathrm{BB} /$ Wor rats exposed to sustained hyperglycemia Metab. Clin. Exp. 39:614-618.

32. Davalli, A. M., C. Ricordi, C. Socci, S. Braghi, F. Bertuzzi, B. Fattor, V. DiCarlo, A. E. Pontiroli, and G. Pozza. 1991. Abnormal sensitivity to glucose of human islets cultured in a high glucose medium: partial reversibility after an additional culture in a normal glucose medium. J. Clin. Endocrinol. \& Metab. 72:202-208.

33. Zawalich, W. S., K. C. Zawalich, G. I. Shulman, and L. Rosseti. 1990. Chronic in vivo hyperglycemia impairs phosphoinositide hydrolysis and insulin release in isolated perfused islets. Endocrinology. 126:253-260.

34. Marynissen, G., V. Leclercq-Meyer, A. Sener, and W. J. Malaisse. 1990. Perturbation of pancreatic islet function in glucose-infused rats. Metab. Clin. Exp. 39:87-95.

35. Sako, Y., and V. E. Grill. 1990. Coupling of $\beta$-cell desensitization by hyperglycemia to excessive stimulation and circulating insulin in glucose-infused rats. Diabetes. 39:1580-1583.

36. Sako, Y., D. Eizirik, and V. E. Grill. 1992. Impact of uncoupling glucose stimulus from secretion on B-cell release and biosynthesis. Am. J. Physiol. 262:E150-E154

37. Scharp, D. W., P. E. Lacy, J. V. Santiago, C. S. McCullough, L. G. Weide, L. Falqui, P. Marchetti, R. L. Gingerich, A. S. Jaffe, P. E. Cryer, et al. 1990. Insulin independence after islet transplantation into type I diabetic patient. Diabetes. 39:515-518.

38. Warnock, G. L., N. M. Kneteman, E. Ryan, R. E. A. Seelis, A. Rabinovitch, and R. V. Rajotte. 1991. Normoglycaemia after transplantation of freshly isolated and cryopreserved pancreatic islets in type 1 (insulin-dependent) diabetes mellitus. Diabetologia. 34:55-58.

39. Kämpe, O., A. Andersson, E. Björk, A. Hallberg, and F. A. Karlsson. 1989. High-glucose stimulation of $64,000-\mathrm{Mr}$ islet cell autoantigen expression. Diabetes. 38:1326-1328.

40. Buschard, K. 1991. The functional state of the beta cells in the pathogenesis of insulin-dependent diabetes mellitus. Autoimmunity. 10:65-69. 